Article

\title{
Biosynthesis of Silver Nanoparticles Using Onion Endophytic Bacterium and Its Antifungal Activity against Rice Pathogen Magnaporthe oryzae
}

\author{
Ezzeldin Ibrahim ${ }^{1,2}$, Jinyan Luo ${ }^{3}$, Temoor Ahmed ${ }^{1}$, Wenge $\mathrm{Wu}^{4}$, Chenqi Yan ${ }^{5, *}$ and Bin Li ${ }^{1, *(1)}$ \\ 1 State Key Laboratory of Rice Biology, Ministry of Agriculture Key Laboratory of Molecular Biology of Crop \\ Pathogens and Insects, Institute of Biotechnology, Zhejiang University, Hangzhou 310058, China; \\ ezzelbehery8818@yahoo.com (E.I.); temoorahmed@zju.edu.cn (T.A.) \\ 2 Department of Vegetable Diseases Research, Plant Pathology Research Institute, Agriculture Research \\ Centre, Giza 12916, Egypt \\ 3 Department of Plant Quarantine, Shanghai Extension and Service Center of Agriculture Technology, \\ Shanghai 201103, China; toyanzi@126.com \\ 4 Rice Research Institute, Anhui Academy of Agricultural Sciences, Hefei 230001, China; \\ wuwenge@aaas.org.cn \\ 5 Institute of Biotechnology, Ningbo Academy of Agricultural Sciences, Ningbo 315040, China \\ * Correspondence: yanchengqi@zaas.ac.cn (C.Y.); libin0571@zju.edu.cn (B.L.)
}

Received: 30 September 2020; Accepted: 14 November 2020; Published: 18 November 2020

\begin{abstract}
Biosynthesis of silver nanoparticles (AgNPs) using endophytic bacteria is a safe alternative to the traditional chemical method. The purpose of this research is to biosynthesize AgNPs using endophytic bacterium Bacillus endophyticus strain $\mathrm{H} 3$ isolated from onion. The biosynthesized AgNPs with sizes from 4.17 to $26.9 \mathrm{~nm}$ were confirmed and characterized by various physicochemical techniques such as Fourier transform infrared spectroscopy (FT-IR), X-ray diffraction (XRD), UV-visible spectroscopy, transmission electron microscopy (TEM) and scanning electron microscopy (SEM) in addition to an energy dispersive spectrum (EDS) profile. The biosynthesized AgNPs at a concentration of $40 \mu \mathrm{g} / \mathrm{mL}$ had a strong antifungal activity against rice blast pathogen Magnaporthe oryzae with an inhibition rate of $88 \%$ in mycelial diameter. Moreover, the biosynthesized AgNPs significantly inhibited spore germination and appressorium formation of M. oryzae. Additionally, microscopic observation showed that mycelia morphology was swollen and abnormal when dealing with AgNPs. Overall, the current study revealed that AgNPs could protect rice plants against fungal infections.
\end{abstract}

Keywords: endophytic bacteria; silver nanoparticles; Magnaporthe oryzae; antifungal activity

\section{Introduction}

Rice (Oryza sativa L.) is the largest food crop in the world [1,2]. One of the basic hindrances to the growth of rice crops is the infection of various fungal diseases, particularly rice blast disease caused by Magnaporthe oryzae, which poses a serious threat to global food safety through the loss of $10-30 \%$ of rice production, enough rice for about 60 million people [1,3,4]. Current control of rice blast disease mainly depends on the use of fungicides. However, the desired goal of controlling the disease has not so far been achieved and there are serious consequences of the excessive use of fungicide on humans, ecosystems and the production of fungicide-resistant strains [5,6]. For all these risks, it is extremely important to find an alternative way to control rice blast disease. Nanotechnology can revolutionize the agricultural and food industry with new tools such as molecular plant disease management, fast disease revelation and the improvement of plants' ability to uptake nutrients. Furthermore, nanotechnology can enhance 
our biological knowledge of a variety of plants and therefore can improve crops or nutritional values as well as develop improved systems to monitor environmental conditions and enhance plants' ability to uptake nutrients or pesticides [7]. Therefore, the application of nanotechnology in agriculture for the control of plant diseases is a safe and eco-friendly alternative to synthetic chemical fungicides $[8,9]$. It has been instrumental in suppressing many of the fungal pathogens that attack the plants, causing them huge loss. For example, silver nanoparticles (AgNPs) had a significant effect in suppressing many of the air, seed and soil-borne fungal plant pathogens $[9,10]$. AgNP synthesis was documented using various methods including physical, chemical, and biological [11,12]. However, biological methods are safer than conventional physical and chemical methods [13,14]. It is a simple process (single vessel installation), rapid, cheap and eco-friendly. Furthermore, the polyphenols and various proteins existent in bio-sources work as a reducing agent, decreasing the use of dangerous external chemical reducing agents and, thus, toxicity. The green synthesis procedure does not require any additional capping agents, which further reduces the cost and simplifies the synthetic process. In contrast, chemical and physical methods are highly restricted in large scale applications, and also have high cost, use high energy, waste time and have difficulty in removing waste [15]. One of the most important biological methods to biosynthesize silver nanoparticles is the use of microorganisms such as bacteria, fungi and algae [11]. In this study, for the first time we biosynthesized new AgNPs using cell-free supernatants (CFSs) of endophytic bacterium B. endophyticus strain $\mathrm{H} 3$ and examined their characterization as a fungicide to inhibit $M$. oryzae.

\section{Materials and Methods}

\subsection{Microorganisms}

The virulent strain Gry of M. oryzae, was obtained from the Institute of Biotechnology, Zhejiang University, Hangzhou, China. Strain H3 of the endophytic bacterium isolated from onion plants was used for biosynthesis of AgNPs.

\subsection{Isolation of Endophytic Bacterium}

The entophytic bacterium was isolated from healthy onion plants collected from different locations in Hangzhou, China, according to [16] with slight modification. In brief, onion plants were collected at the seedling stage. The plants were washed carefully with tap water to remove the soil, then dried, and classified into leaves and roots. Onion leaves were cut into small pieces $(2-3 \mathrm{~cm})$ and disinfected with alcohol (70\%) for $1 \mathrm{~min}$ followed by sodium hypoxy-chloride (1\%) for $5 \mathrm{~min}$ and rinsed three times with sterile water under sterile conditions. One gram of sterile tissues was crushed separately in $9 \mathrm{~mL}$ saline water $(0.85 \% \mathrm{NaCl})$, followed by serial dilution up to $10^{-5}$. For each of these dilutions, $0.1 \mathrm{~mL}$ was spread on nutrient agar (NA) medium $[8,11,12]$ bought from Sangon Biotech, Shanghai, and incubated for two days at $30^{\circ} \mathrm{C}$. The colonies were purified by transferring single colonies to a new NA plate. The isolated strains were stored in $30 \%(v / v)$ glycerol at $-80{ }^{\circ} \mathrm{C}$ until use.

\subsection{Identification of Endophytic Bacterium}

The isolated endophytic bacterium was identified through 16S rRNA gene sequence analysis. The isolate was grown for $24 \mathrm{~h}$ in NA medium and a single colony was transferred to NA broth and incubated in a shaker at $30^{\circ} \mathrm{C}$ overnight. Bacterial DNA was isolated using a genomic bacterial DNA isolation Kit (Sangon Biotech (Shanghai) Co, Ltd., Shanghai, China) following the instructions in the protocol. The 16S rRNA gene was amplified by the bacterial-specific primer pairs $27 \mathrm{~F}$ (AGAGTTTGATCGCTGCTCAG) and 1492F (GGTTACCTTGTTACGACTT) [17,18]. Complete volumes of PCR amplification in $50 \mu \mathrm{L}$ were performed using the Bioer XP Thermal Cycler (Hangzhou Bioer Tech. Co., Ltd., Hangzhou, China) in $2 \times$ TSINGKE PCR Master Mix (TsingKe Biotechnology, Beijing, China). PCR parameters including the following cycles: the initial denaturation stage was $95^{\circ} \mathrm{C}$ for $5 \mathrm{~min}$ and 30 cycles followed, each of which consisted of denaturation at $94^{\circ} \mathrm{C}$ for $30 \mathrm{~s}$, annealing at 
$53{ }^{\circ} \mathrm{C}$ for $30 \mathrm{~s}$, and extending at $72{ }^{\circ} \mathrm{C}$ for $1 \mathrm{~min}$. The final extension step was carried out for $5 \mathrm{~min}$ at $72{ }^{\circ} \mathrm{C}$. PCR amplicons were verified by using Agarose Gel electrophoresis (1\%). PCR products were purified by StarPrep Gel Extraction Kit (GeneStar, Beijing, China) and finally submitted for DNA sequencing in TsingKe Biological Technology, Beijing, China. The 16S rRNA gene sequence of the endophytic bacterium was aligned against a reference database using the BLAST server at National Center for Biotechnology Information (NCBI) (http://www.ncbi.nlm.nih.gov). The phylogenetic tree was constructed using the MEGA 6.0 program and the neighbour-joining method [19]. The sequence was deposited in the NCBI database.

\subsection{Preparation of the Cell-Free Supernatants of Endophytic Bacterium}

The cell-free supernatants (CFSs) of the selected endophytic bacterium were prepared according to [20], with slight modification. In brief, Bacillus endophyticus strain $\mathrm{H} 3$ was inoculated in NA liquid medium and incubated at $30^{\circ} \mathrm{C}$ and $200 \mathrm{rpm}$ for 2 days. The CFSs were purified by centrifugation of bacterial culture (approximately $\sim 1 \times 10^{8} \mathrm{CFU} / \mathrm{mL}$ ) at $10,000 \mathrm{rpm}$, at $4{ }^{\circ} \mathrm{C}$ for $20 \mathrm{~min}$, and twice by using filter sterilization $0.22 \mu \mathrm{m}$. To rule out possible contamination, $100 \mu \mathrm{L}$ of CFSs were spread on NA agar for one day. The CFSs were kept at $4{ }^{\circ} \mathrm{C}$ till their use in the biosynthesis of AgNPs.

\subsection{Biosynthesis of $A g N P s$}

Silver nitrate (Cat. no. 10018461; Sinopharm, Shanghai, China) was used to synthesize AgNPs according to [9], with slight modification. Briefly, $10 \mathrm{~mL}$ of CFSs were added to $90 \mathrm{~mL}$ of $3 \mathrm{mM}$ $\mathrm{AgNO}_{3}$ aqueous solution in a $250 \mathrm{~mL}$ Erlenmeyer flask and then incubated at $30^{\circ} \mathrm{C}$ in a rotary shaker at $200 \mathrm{rpm}$ for $3 \mathrm{~d}$ in the dark. As a control, $10 \mathrm{~mL}$ of NA broth with the same volume of $\mathrm{AgNO}_{3}$ was used. The successful biosynthesis of AgNPs will convert the colour from yellow light to dark brown, which can be determined by using UV-Visible spectrometry (Shimadzu UV-2550 spectrometer) in the wavelength range of $200-800 \mathrm{~nm}$ at a resolution of $1 \mathrm{~nm}$. The resulting pellets were collected from AgNPs by centrifugation at 10,000 $\mathrm{g}$ for $20 \mathrm{~min}$, purified by washing twice with sterile doubledistilled water $\left(\mathrm{ddH}_{2} \mathrm{O}\right)$ and stored at $-80^{\circ} \mathrm{C}$.

\subsection{Characterization of the Biosynthesized AgNPs}

Characterization of the biosynthesized AgNPs was performed by using several techniques. Fourier transform infrared (FTIR) was performed to identify the functional groups of the CFSs responsible for reducing Ag ion to AgNPs; transmission electron microscopy (TEM), scanning electron microscopy (SEM) and energy dispersive spectrum (EDS) as well as X-ray diffraction (XRD) were performed to study the size and morphology and to ensure the presence of silver ion in the resulting pellets of AgNPs.

\subsubsection{FTIR}

The functional group of the biosynthesized AgNPs was planned by FTIR as described by [14]. Briefly, $1 \mathrm{mg}$ (freeze-dried) of AgNPs powders were blended with $\mathrm{KBr}(300 \mathrm{mg}$ ) and the FTIR were measured with an AVATAR 370 FTIR spectrometer (Thermo Nicolet, MA, USA) at a spectral range of $500-4000 \mathrm{~cm}$.

\subsubsection{XRD}

The crystalline phase of AgNPs was determined based on XRD analysis, which was carried out on an XPert PRO diffractometer (Holland) with a detector voltage of $45 \mathrm{kV}$ and a current of $40 \mathrm{~mA}$ using $\mathrm{CuKo}$ radiation as described in the methods of [13]. 


\subsubsection{TEM, SEM and EDS}

The structural morphology and AgNP sizes were studied by TEM and SEM observation using a Transmission Electron Microscopy (JEM-1230, JEOL, Akishima, Japan) and Scanning Electron Microscopy (TM-1000, Hitachi, Japan) according to the method of [12]. In short, the AgNPs powder was equipped with a copper-coated grid and a carbon-coated grid, respectively, for one day at room temperature to form a film of the sample. The existence of silver ion was confirmed by energy dispersive spectrum (EDS).

\subsection{Antifungal Activity of the Biosynthesized AgNPs}

\subsubsection{Effect of AgNPs on Mycelium Growth}

The inhibitory effect of AgNPs at four concentrations (10,20, 30 and $40 \mu \mathrm{g} / \mathrm{mL}$ ) on mycelium growth of M. oryzae strain Gry was determined using an agar medium test as described by [9], with slight modification. In brief, a disk (10-mm in diameter) of 7-day-old mycelium was inoculated in the centre of the petri dishes ( $9 \mathrm{~cm}$ in diameter), containing the blend of Potato Dextrose Agar (PDA) medium ( $\mathrm{pH}$ 7.0), at several concentrations of AgNPs. The PDA plates were used without AgNPs as a control. The diameter of the fungus colony was measured after $7 \mathrm{~d}$ of incubation at $27^{\circ} \mathrm{C}$ and then the inhibition of mycelium growth was calculated.

\subsubsection{Effect of AgNPs on Cell Wall Morphology}

Damage to the cell wall of M. oryzae strain Gry was determined using AgNPs according to the method of [21], with minor modification. In short, a mycelial disc of M. oryzae strain Gry (10-mm in diameter) was brought from PDA medium, treated and not treated by AgNPs, and examined by using both SEM (TM-1000, Hitachi, Japan) and TEM (JEM-1230, JEOL, Akishima, Japan).

\subsubsection{Effect of AgNPs on Spore Germination and Length of Germ Tubes}

The influence of four concentrations $(10,20,30$ and $40 \mu \mathrm{g} / \mathrm{mL})$ of AgNPs on the germination of spores and length of germ tubes of M. oryzae strain Gry were identified as described by [22], with slight modification. Briefly, $500 \mu \mathrm{L}$ of spore suspension $\left(1 \times 10^{5}\right.$ spores $\left./ \mathrm{mL}\right)$ that were prepared according to the method of [23], were added to the same volume of AgNPs in $1 \mathrm{~mL}$ tubes with a final concentration of 10, 20, 30 and $40 \mu \mathrm{g} / \mathrm{mL}$. Mixed spore suspensions with $\mathrm{ddH}_{2} \mathrm{O}$ were used as the control. The germination rate of spores and length of germ tubes of M. oryzae strain Gry was recorded after $24 \mathrm{~h}$ of incubation at $28^{\circ} \mathrm{C}$ in the dark, using the light microscope. The experiment was repeated twice with three replicates.

\subsubsection{Effect of AgNPs on Appressorium Formation}

The influence of four concentrations $(10,20,30$ and $40 \mu \mathrm{g} / \mathrm{mL})$ of AgNPs on the appressorium formation of M. oryzae strain Gry was assessed according to [6], with slight modification. In brief, $500 \mu \mathrm{L}$ of spore suspension $\left(1 \times 10^{5}\right.$ spores $\left./ \mathrm{mL}\right)$ was added to the same volume of AgNPs in $1 \mathrm{~mL}$ tubes with a final concentration of $10,20,30$ and $40 \mu \mathrm{g} / \mathrm{mL}$. Spore suspensions with $\mathrm{ddH}_{2} \mathrm{O}$ were added as a control. The inhibitory effect of AgNPs on numbers and sizes of appressoria were recorded after $72 \mathrm{~h}$ of incubation at $28^{\circ} \mathrm{C}$ in the dark, using the light microscope.

\subsection{Statistical Analysis}

All experiments were performed randomly and the results were shown as the mean \pm SD (standard deviation). Statistical analysis was performed with the SPSS version software package 16.0 (SPSS Inc., Chicago, IL, USA). Differences between the groups were estimated using different test analyses. When the $p$ value is $<0.05$ or 0.01 , the result is statistically significant. 


\section{Results and Discussion}

\subsection{Isolation and Identification of the Endophytic Bacterium}

Endophytic bacteria live inside of plants without causing harm to the host plant [24]. In our study, we obtained a total of 17 endophytic bacterial isolates from the interior of onion leaves. One isolate, namely, H3 was selected based on its ability in the biosynthesis of AgNPs. This isolate was subjected to molecular identification. Partial 16S rRNA gene sequence analysis revealed that the selected isolate was belonging to the genus of Bacillus (Figure 1), and subjected to GenBank under accession number MN611116.

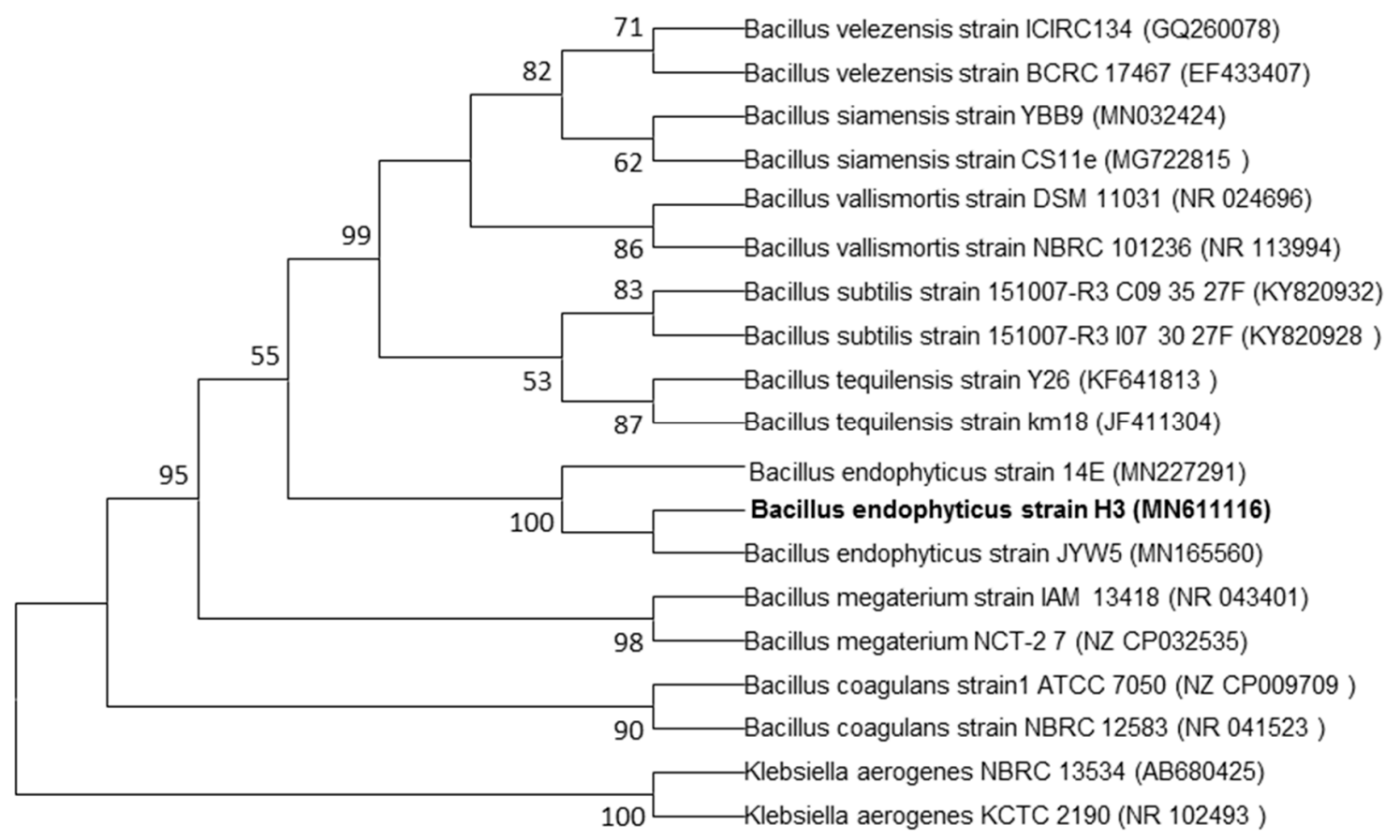

Figure 1. Phylogenetic tree of endophytic bacterium B. endophyticus strain $\mathrm{H} 3$ isolated from onion leaves in the seedling stage constructed by using $16 \mathrm{~S}$ rRNA gene sequences. Bootstrap analysis (1000 replicates) for node values greater than $50 \%$ are given. Bar 0.02 substitutions per nucleotide position.

\subsection{Biosynthesis and Characterization of AgNPs}

CFSs obtained from endophytic bacterium B. endophyticus strain $\mathrm{H} 3$ were tested in the biosynthesis of AgNPs in $3 \mathrm{mM}$ of $\mathrm{AgNO}_{3}$ solution. Incubation of $10 \mathrm{~mL}$ of CFSs with $90 \mathrm{~mL}$ of $\mathrm{AgNO}_{3}$ for three days resulted in color conversion from light yellow to dark brown, demonstrating the development of nanoparticles in the reaction mix. Differences in the color of AgNPs have been reported due to the formation of the biomolecules responsible for the synthesis of nanoparticles and the reduction of $\mathrm{Ag}^{+}$to $\mathrm{Ag}^{0}[9,12,13,25]$. The reduction of silver ion $\left(\mathrm{Ag}^{+}\right)$of $\mathrm{AgNO}_{3}$ has been found in many bacterial species, such as the Bacillus siamensis strain C1 [14] and Pseudomonas rhodesiae [13]. During the reduction of AgNO $\mathrm{N}_{3}$, the nitrate ions $\left(\mathrm{NO}_{3}{ }^{-}\right)$are reduced to nitrite $\left(\mathrm{NO}_{2}^{-}\right)$by firstly accepting two protons and then releasing two electrons and water. The electrons emitted in the reduction reaction are transferred to the $\mathrm{Ag}^{+}$to form the silver element $\mathrm{Ag}^{0}[26,27]$.

Furthermore, the formation of nanoparticles in the mixture was confirmed by a UV spectrophotometer, which showed a spectrum of surface plasmon resonance (SRP) at 412 nm (Figure 2), which is within the range reported earlier [13,28,29]. Similarly, Ahmed et al. [30] confirmed the formation of biogenic AgNPs in the reaction mixture by the presence of the peak at $418 \mathrm{~nm}$.

TEM and SEM observations showed the nanoparticle to have spherical shape with sizes ranging from 4.17 to $26.9 \mathrm{~nm}$ in the reaction mixture (Figure 3). The present observations are consistent with the results from previous reports [13,31,32]. The toxicity of AgNPs depends on the variation of particle size. 
AgNPs have an important influence on fungal cell's viability and ROS generation in a size-dependent manner. It is evident that the surface area, the volume ratio and the interaction of the surface with the particle size can be changed. Furthermore, sedimentation rate, mass diffusion, binding efficiency and sedimentation rate of NPs on biological or solid surfaces are highly influenced by particle size [33]. For example, Carlson et al. found that the $15 \mathrm{~nm}$ AgNPs can produce more ROS compared to $55 \mathrm{~nm}$ AgNPs in a macrophage cell line [34]. Furthermore, the EDS result showed that the element peak of silver, silica and sulfur are 92.77, 5.53 and $1.70 \%$, respectively, in the reaction mixture (Figure 4). The results of this study are in agreement with the literature related to silver nanoparticles, where the silver ions peak was confirmed at $3 \mathrm{KeV}[30,35]$.

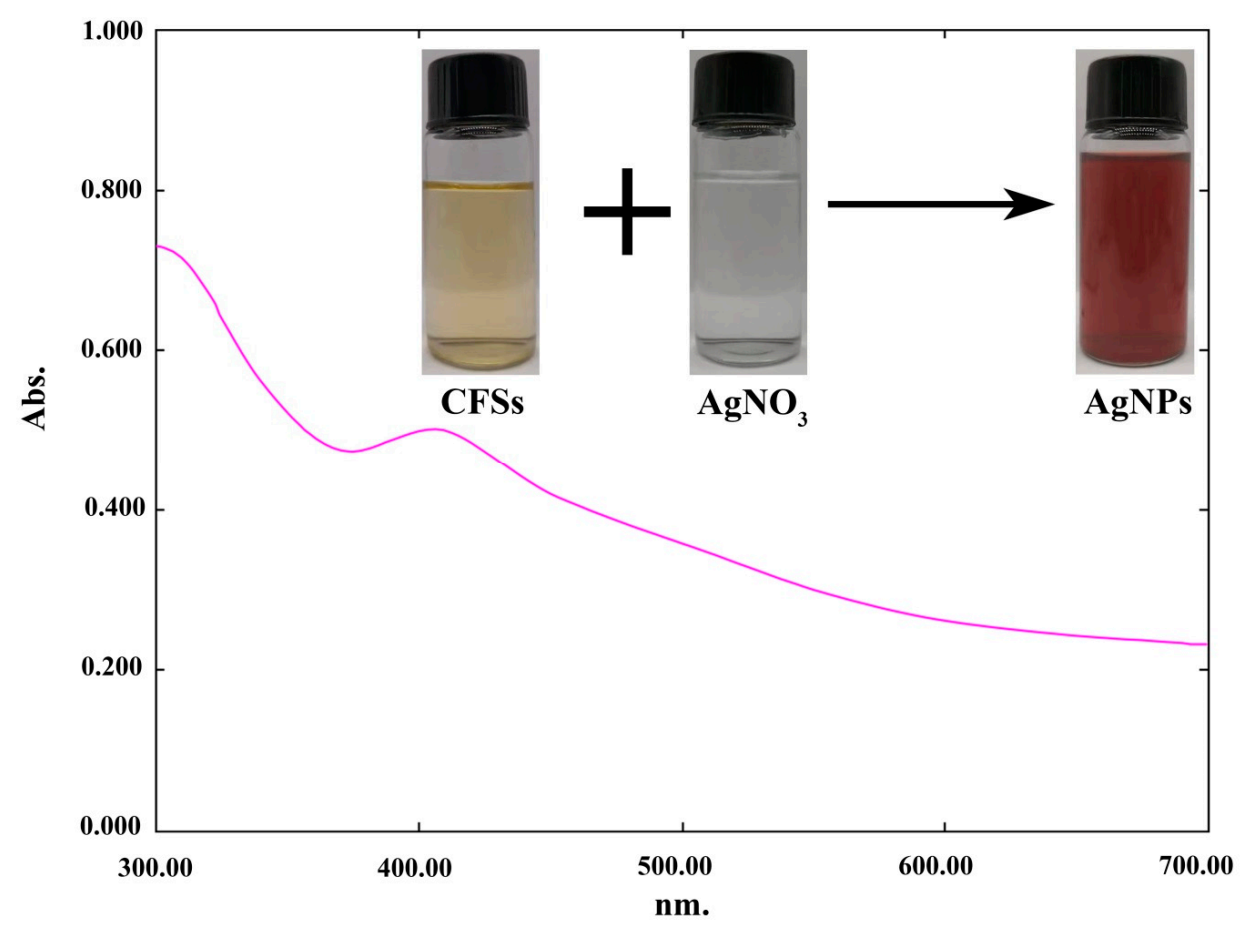

Figure 2. UV-vis absorption spectra of green silver nanoparticles (AgNPs) in the reaction mixture.
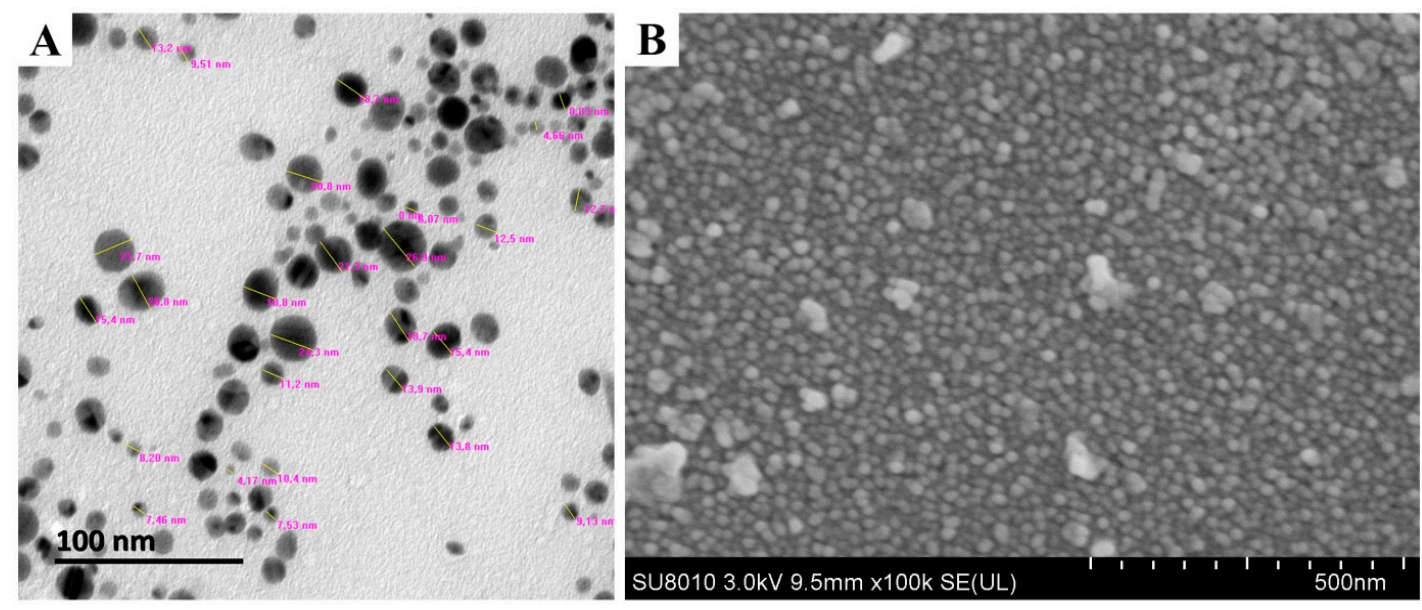

Figure 3. Characterization of AgNPs biosynthesized by using culture filtrates of B. endophyticus strain H3 isolated from onion. (A) Transmission electron microscopy and (B) scanning electron microscopy. 

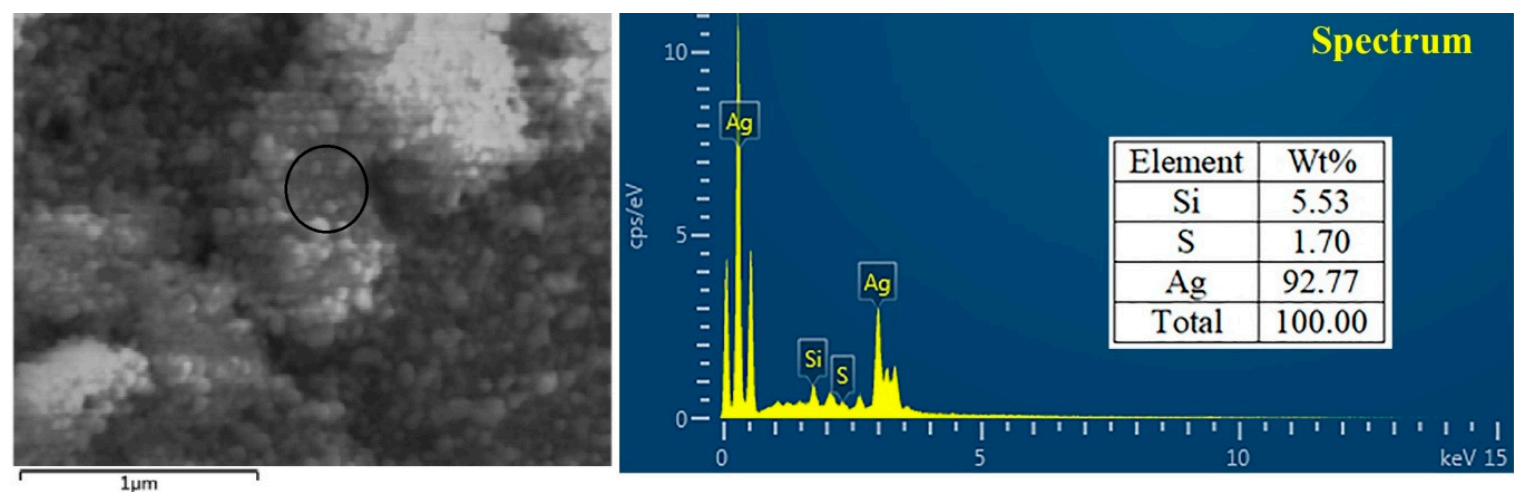

Figure 4. Characterization of biosynthesized AgNPs by using energy dispersive spectrum (EDS).

The functional groups of the biosynthesized AgNPs were confirmed by using FTIR analysis. In fact, 6 peaks at 3416, 2924, 1635, 1395, 1062 and $516 \mathrm{~cm}^{-1}$ were observed in the FTIR spectra of the synthesized AgNPs, which are shown in (Figure 5A). The main peak of $3416 \mathrm{~cm}^{-1}$ is due to the N-H stretching vibrations; a characteristic peak at $1635 \mathrm{~cm}^{-1}$ represents $\mathrm{C}=\mathrm{O}$ carbonyl group and $\mathrm{C}=\mathrm{C}$ stretching vibrations; the peaks at 2924, 1395 and $1062 \mathrm{~cm}^{-1}$ represent the $\mathrm{C}-\mathrm{H}$ stretching vibrations, $\mathrm{C}=\mathrm{N}$ bond of Amide II, O-H deformation vibrations, and $\mathrm{C}-\mathrm{N}$ stretching amine vibrations, respectively; the peak at $516 \mathrm{~cm}^{-1}$ represents $\mathrm{C}-\mathrm{Br}$ stretching. The existence of such groups in the chlorofluorocarbons (CFCs) from endophytic bacterium confirms the presence of proteins and indicates that these functional groups have a major role in reducing $\mathrm{Ag}^{+}$to $\mathrm{Ag}^{0}[13,32,36]$. Similarly, various studies reported the presence of functional groups representing different macromolecules, such as nucleic acids, proteins, lipids, carbohydrates and sugars, surrounding the green NPs which prevents the oxidation and deterioration of nanoparticles [30,37,38].
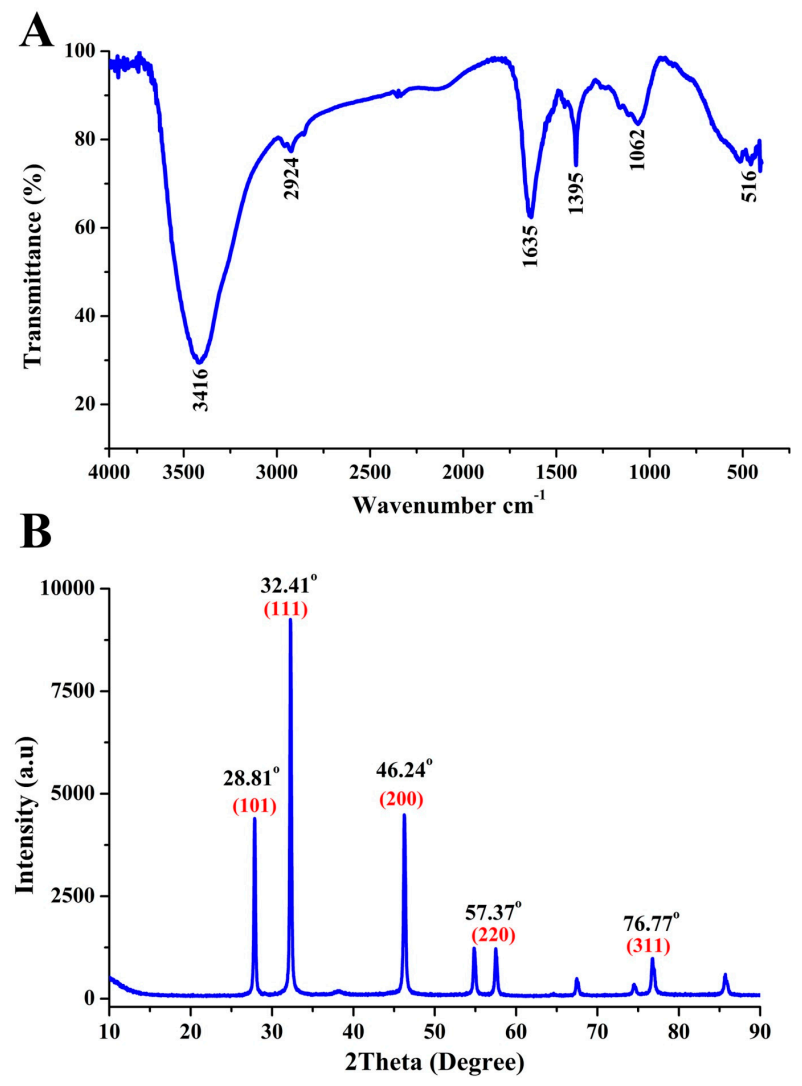

Figure 5. Characterization of the biosynthesized AgNPs. (A) Fourier transform infra-red (FTIR) spectra. (B) X-ray diffraction (XRD) spectra. 
The crystalline structure of the biogenic AgNPs was determined through the XRD analysis result, that showed five emission peaks of $2 \theta=28.81^{\circ}, 32.41^{\circ}, 46.24^{\circ}, 57.37^{\circ}$ and $76.77^{\circ}$, compatible with crystalline silver planes (101), (111), (200), (220), (311), respectively (Figure 5B). Similar results have been reported in other studies $[11,14,38]$.

\subsection{Antifungal Activity of AgNPs}

The result of antifungal activity revealed that the mycelium growth of $M$. oryaze strain Gry was robustly suppressed by AgNPs, shown in (Figure 6). The inhibitory effect on the growth of mycelium increased with the increase of AgNP concentrations. In fact, AgNPs at 10, 20, 30 and $40 \mu \mathrm{g} / \mathrm{mL}$ caused an $18 \%, 49 \%, 65 \%$ and $88 \%$ reduction, respectively, in mycelial diameter. Similarly, previous studies have shown that AgNPs can be used as an antifungal agent to prevent plants from fungal infection [9,10,39-43]. Although there are different hypotheses available, the antimicrobial mechanisms of AgNPs have not yet been clearly defined. The proposed mechanisms were summarized based on the current literature, as follows: attachment of AgNPs to the surface of the cell membrane, altering the lipid bilayer or increasing permeability of the cell membrane, microbial cell intrusion of AgNPs causing damage to intracellular micro organelles (such as mitochondria, vacuoles and ribosomes) and biomolecules including DNA, protein and lipids, and modulation of the intracellular signal transduction method towards apoptosis [44].

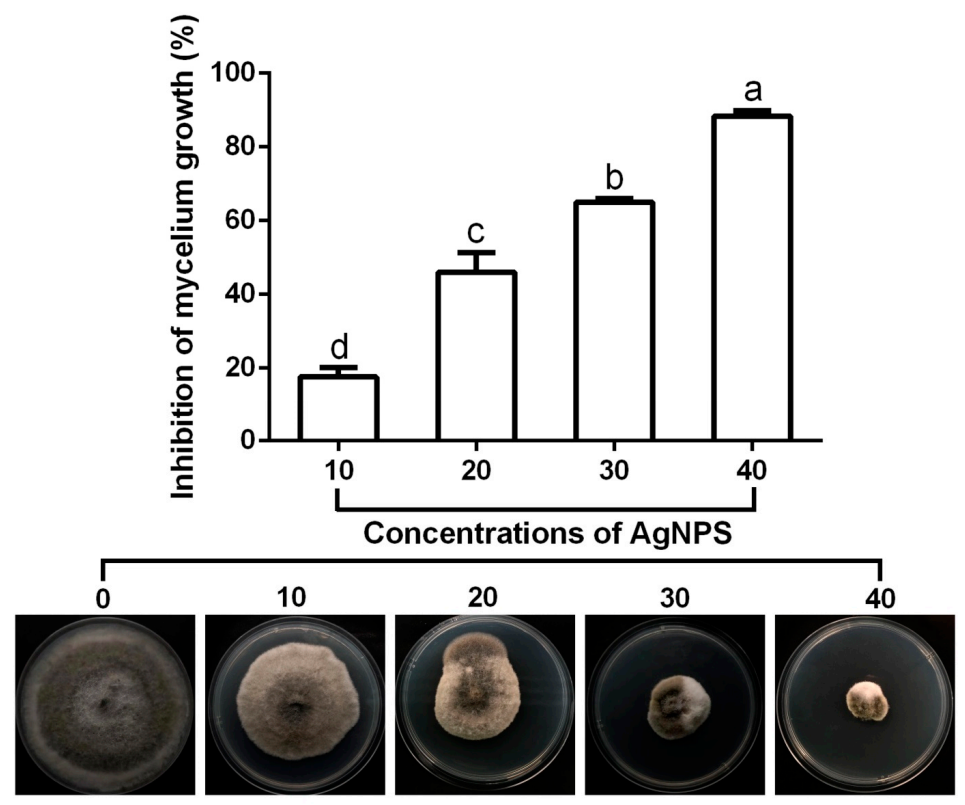

Figure 6. Effect of the biosynthesized AgNPs at four different concentrations (10, 20, 30 and $40 \mu \mathrm{g} / \mathrm{mL}$ ) on the mycelial growth of M. oryaze strain Gry. The AgNPs at 10, 20, 30 and $40 \mu \mathrm{g} / \mathrm{mL}$ caused an $18 \%$, $49 \%, 65 \%$ and $88 \%$ reduction, respectively, in mycelial diameter. Data are a mean value \pm standard error of three replicates, and bars with different letters (a-d) are significantly different in LSD test.

The fungal cell wall is a flexible structure that performs several functions in determining the shape of the cell. In addition, the cell wall can protect the fungal cells from environmental stresses, such as $\mathrm{pH}$, temperature and changes in osmolality [9,45]. Therefore, interference by causing harm to the fungal cell wall may lead to loss of content and death. In our results, the hyphae of $M$. oryzae strain Gry that were treated with AgNPs showed abnormal structural, swelling and damage to their cell walls causing some loss of contents. In contrast, the cell walls of M. oryzae strain Gry had normal structural characteristics in the absence of the AgNPs (Figure 7). Similarly, the antifungal activity of AgNPs and $\mathrm{Cu}-\mathrm{NPs}$ have been found on the cell walls of many pathogenic fungi such as Fusarium graminearum, Fusarium oxysporum, Fusarium solani and Colletotrichum gloeoesporioides $[9,45,46]$. 
The germinated spores of pathogenic fungi are known to perform a major role in colonizing and infecting plants $[9,47]$. Therefore, inhibition rate of spore germination will significantly reduce the threat of rice fungal pathogens. The biosynthesized AgNPs were able to efficiently inhibit the spore germination and germ tube growth of M. oryzae strain Gry, and the antifungal activity increased with the increase in AgNP concentration. In fact, the germination rate of spores was 83\%, while the length of the germ tubes was $77.63 \mu \mathrm{m}$ in the negative control. However, the germination rate of spores was $68 \%, 53 \%, 31 \%$ and $13 \%$, respectively (Figure $8 \mathrm{~A}$ ), while the germ tubes length was $54.62 \mu \mathrm{m}$, $33.73 \mu \mathrm{m}, 21.74 \mu \mathrm{m}$ and $8.11 \mu \mathrm{m}$, respectively, (Figure 8B) in the presence of AgNPs at four different concentrations $(10,20,30$ and $40 \mu \mathrm{g} / \mathrm{mL})$. Similar results have also been reported in other studies $[9,48]$.

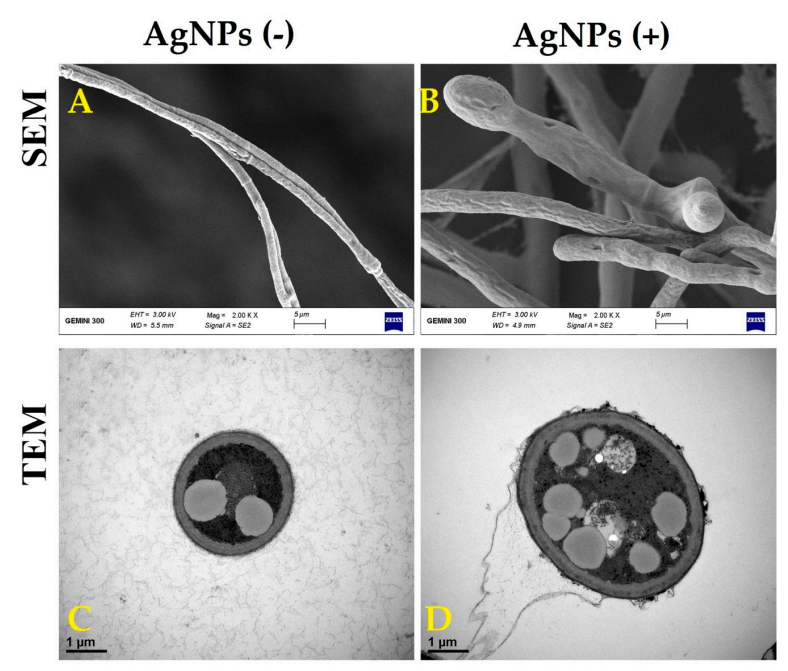

Figure 7. Scanning electron microscopy (SEM) [scale bar $=5 \mu \mathrm{m}$ ] and transmission electron microscopy (TEM) [scale bar $=1 \mu \mathrm{m}$ ] images of M. oryaze strain Gry in the absence of the biosynthesized AgNPs; the hyphae showed a normal structural property $(\mathbf{A}, \mathbf{C})$, and in the presence of the biosynthesized AgNPs, it had abnormal structure, swelling and damage to the cell walls' contents (B,D).
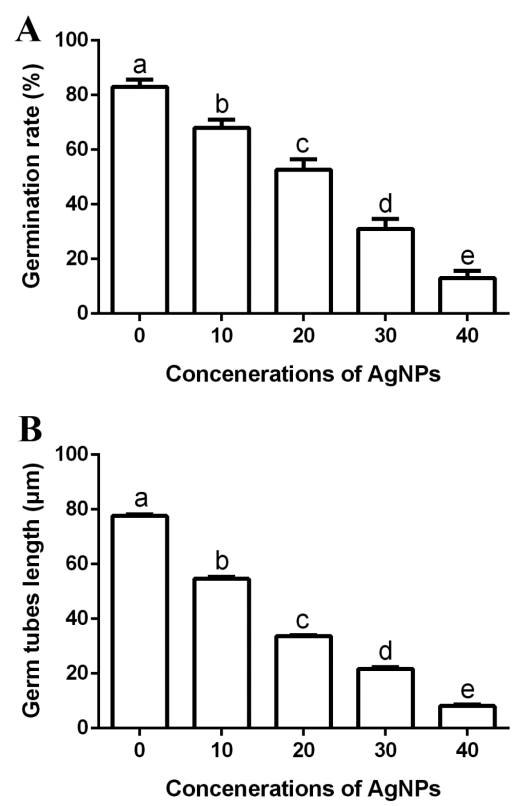

Figure 8. Effect of the biosynthesized AgNPs of four different concentrations (10, 20, 30 and $40 \mu \mathrm{g} / \mathrm{mL}$ ) on spores' germination rate (A) and germ tube growth $(\mathbf{B})$. Data are a mean value \pm standard error of three replicates, and bars with different letters (a-e) are significantly different in LSD test. 
Many fungi form a specialized infection structure called an appressorium that is necessary and required to penetrate the plant cell walls $[1,6]$. Therefore, appressorium inhibition significantly reduces the risk of rice fungal pathogens. The biosynthesized AgNPs were able to effectively inhibit the appressorium formation and appressorium diameter of M. oryzae strain Gry, while the inhibitory effect increased along with the increase in AgNP concentration. In fact, the appressorium formation rate was $83 \%$, while appressorium diameter was $14.00 \mu \mathrm{m}$ in the negative control. However, the appressorium formation rate was $66 \%, 34 \%, 11 \%$ and $0 \%$, respectively (Figure $9 \mathrm{~A}$ ), while the appressorium diameter was $11.00 \mu \mathrm{m}, 8.00 \mu \mathrm{m}, 5.38 \mu \mathrm{m}$ and $0.00 \mu \mathrm{m}$, respectively (Figure 9B) in the presence of AgNPs at different concentrations $(10,20,30$ and $40 \mu \mathrm{g} / \mathrm{mL})$.
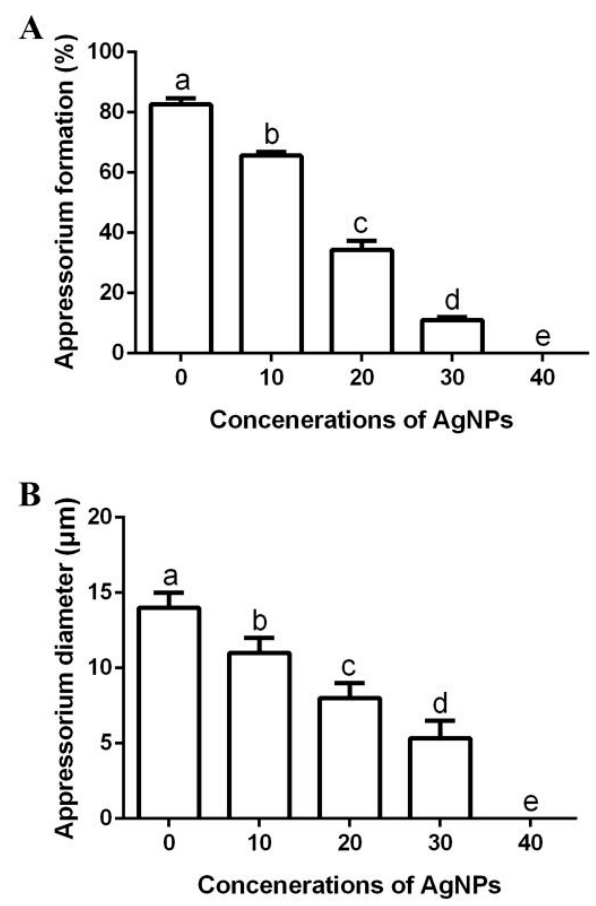

Figure 9. Effect of the biosynthesized AgNPs of four different suspensions (10, 20, 30 and $40 \mu \mathrm{g} / \mathrm{mL}$ ) on appressorium formation $(\mathbf{A})$ and appressorium diameter $(\mathbf{B})$. Data are a mean value \pm standard error of three replicates, and bars with different letters (a-e) are significantly different in LSD test.

\section{Conclusions}

The green synthesis of AgNPs is a safe alternative to physical and chemical methods. The present study reports for the first time the biosynthesis of AgNPs by using endophytic bacterium isolated from onion. The formation of biogenic AgNPs was further confirmed through UV-vis spectroscopy, FTIR, XRD, SEM, TEM and EDS. In addition, the biosynthesized AgNPs exhibited robust antifungal activity against rice blast pathogen $M$. oryaze strain Gry, which may be mainly attributed to their ability to inhibit spore germination, germ tube growth, appressorium formation and damage of cell well. Overall, these results suggest that biosynthesized AgNPs have the potential to protect rice plants from fungal diseases.

Author Contributions: Conceptualization, E.I. and J.L.; Methodology, E.I. and T.A.; Software, E.I. and J.L.; data Investigation, E.I. and J.L.; Supervision, C.Y., W.W. and B.L.; writing-original draft, E.I., T.A. and B.L.; Writing-review \& editing, all the authors contribute to this part. All authors have read and agreed to the published version of the manuscript.

Funding: The work is partially supported by Shanghai Agriculture Applied Technology Development Program (2019-02-08-00-08-F01150), Zhejiang Provincial Natural Science Foundation of China (LZ19C140002), National Natural Science Foundation of China (31872017, 32072472, 31571971, 31801787, 31901925), Zhejiang Provincial Project (2017C02002, 2019C02006, 2020C02006), Key Scientific Technological Project of Ningbo (2016C11017; 2019B10004), National Key Research and Development Program of China (2018YFD0300900; 2017YFD0201104), 
Dabeinong Funds for Discipline Development and Talent Training in Zhejiang University, State Key Laboratory for Managing Biotic and Chemical Treats to the Quality and Safety of Agro-products (2010DS700124-ZZ1907), the Fundamental Research Funds for the Central Universities.

Acknowledgments: We thank for the help in data investigation and analysis from Muchen Zhang, Arshad Ali, Mengju Liu and Solabomi Olaitan Ogunyemi.

Conflicts of Interest: The authors declare no conflict of interest.

\section{References}

1. Cui, S.; Wang, J.; Gao, F.; Sun, G.; Liang, J. Quantitative proteomic analyses reveal that RBBI3. 3, a trypsin inhibitor protein, plays an important role in Magnaporthe oryzae infection in rice. Plant Growth Regul. 2018, 86, 365-374. [CrossRef]

2. Kennedy, D. The importance of rice. Science 2002, 296, 13. [CrossRef] [PubMed]

3. Skamnioti, P.; Gurr, S.J. Against the grain: Safeguarding rice from rice blast disease. Trends Biotechnol. 2009, 27, 141-150. [CrossRef] [PubMed]

4. Dean, R.; Van Kan, J.A.; Pretorius, Z.A.; Hammond-Kosack, K.E.; Di Pietro, A.; Spanu, P.D.; Rudd, J.J.; Dickman, M.; Kahmann, R.; Ellis, J. The Top 10 fungal pathogens in molecular plant pathology. Mol. Plant Pathol. 2012, 13, 414-430. [CrossRef]

5. Gisi, U.; Sierotzki, H.; Cook, A.; McCaffery, A. Mechanisms influencing the evolution of resistance to Qo inhibitor fungicides. Pest Manag. Sci. 2002, 58, 859-867. [CrossRef]

6. Wang, N.; Cai, M.; Wang, X.; Xie, Y.; Ni, H. Inhibitory action of biofungicide physcion on initial and secondary infection of Magnaporthe oryzae. J. Phytopathol. 2016, 164, 641-649. [CrossRef]

7. Prasad, R.; Kumar, V.; Prasad, K.S. Nanotechnology in sustainable agriculture: Present concerns and future aspects. Afr. J. Biotechnol. 2014, 13, 705-713.

8. Abdallah, Y.; Ogunyemi, S.O.; Abdelazez, A.; Zhang, M.; Hong, X.; Ibrahim, E.; Hossain, A.; Fouad, H.; $\mathrm{Li}, \mathrm{B}$.; Chen, J. The green synthesis of $\mathrm{MgO}$ nano-Flowers using Rosmarinus officinalis L.(Rosemary) and the antibacterial activities against Xanthomonas oryzae pv. oryzae. Biomed Res. Int. 2019, 2019, 5620989. [CrossRef]

9. Ibrahim, E.; Zhang, M.; Zhang, Y.; Hossain, A.; Qiu, W.; Chen, Y.; Wang, Y.; Wu, W.; Sun, G.; Li, B. Green-Synthesization of Silver Nanoparticles Using Endophytic Bacteria Isolated from Garlic and Its Antifungal Activity against Wheat Fusarium Head Blight Pathogen Fusarium graminearum. Nanomaterials 2020, 10, 219. [CrossRef]

10. Gupta, N.; Upadhyaya, C.P.; Singh, A.; Abd-Elsalam, K.A.; Prasad, R. Applications of silver nanoparticles in plant protection. In Nanobiotechnology Applications in Plant Protection; Springer: Berlin/Heidelberg, Germany, 2018; pp. 247-265.

11. Masum, M.; Islam, M.; Siddiqa, M.; Ali, K.A.; Zhang, Y.; Abdallah, Y.; Ibrahim, E.; Qiu, W.; Yan, C.; Li, B. Biogenic synthesis of silver nanoparticles using Phyllanthus emblica fruit extract and its inhibitory action against the pathogen Acidovorax oryzae Strain RS-2 of rice bacterial brown stripe. Front. Microbiol. 2019, 10, 820. [CrossRef]

12. Ogunyemi, S.O.; Abdallah, Y.; Zhang, M.; Fouad, H.; Hong, X.; Ibrahim, E.; Masum, M.M.I.; Hossain, A.; Mo, J.; Li, B. Green synthesis of zinc oxide nanoparticles using different plant extracts and their antibacterial activity against Xanthomonas oryzae pv. oryzae. Artif. Cells Nanomed. Biotechnol. 2019, 47, 341-352. [CrossRef] [PubMed]

13. Hossain, A.; Hong, X.; Ibrahim, E.; Li, B.; Sun, G.; Meng, Y.; Wang, Y.; An, Q. Green synthesis of silver nanoparticles with culture supernatant of a bacterium Pseudomonas rhodesiae and their antibacterial activity against soft rot pathogen Dickeya dadantii. Molecules 2019, 24, 2303. [CrossRef] [PubMed]

14. Ibrahim, E.; Fouad, H.; Zhang, M.; Zhang, Y.; Qiu, W.; Yan, C.; Li, B.; Mo, J.; Chen, J. Biosynthesis of silver nanoparticles using endophytic bacteria and their role in inhibition of rice pathogenic bacteria and plant growth promotion. RSC Adv. 2019, 9, 29293-29299. [CrossRef]

15. Mukherjee, S.; Patra, C.R. Biologically synthesized metal nanoparticles: Recent advancement and future perspectives in cancer theranostics. Future Sci. 2017, 3, FSO203. [CrossRef] [PubMed]

16. Yan, X.; Wang, Z.; Mei, Y.; Wang, L.; Wang, X.; Xu, Q.; Peng, S.; Zhou, Y.; Wei, C. Isolation, diversity, and growth-promoting activities of endophytic bacteria from tea cultivars of Zijuan and Yunkang-10. Front. Microbiol. 2018, 9, 1848. [CrossRef] 
17. Masum, M.; Liu, L.; Yang, M.; Hossain, M.; Siddiqa, M.; Supty, M.; Ogunyemi, S.; Hossain, A.; An, Q.; Li, B. Halotolerant bacteria belonging to operational group Bacillus amyloliquefaciens in biocontrol of the rice brown stripe pathogen Acidovorax oryzae. J. Appl. Microbiol. 2018, 125, 1852-1867. [CrossRef]

18. Li, B.; Xu, L.; Lou, M.; Li, F.; Zhang, Y.; Xie, G. Isolation and characterization of antagonistic bacteria against bacterial leaf spot of Euphorbia pulcherrima. Lett. Appl. Microbiol. 2008, 46, 450-455. [CrossRef]

19. Tamura, K.; Peterson, D.; Peterson, N.; Stecher, G.; Nei, M.; Kumar, S. MEGA5: Molecular evolutionary genetics analysis using maximum likelihood, evolutionary distance, and maximum parsimony methods. Mol. Biol. Evol. 2011, 28, 2731-2739. [CrossRef]

20. Almoneafy, A.A.; Kakar, K.U.; Nawaz, Z.; Li, B.; Yang, C.-L.; Xie, G.-L. Tomato plant growth promotion and antibacterial related-mechanisms of four rhizobacterial Bacillus strains against Ralstonia solanacearum. Symbiosis 2014, 63, 59-70. [CrossRef]

21. Gao, T.; Zhou, H.; Zhou, W.; Hu, L.; Chen, J.; Shi, Z. The fungicidal activity of thymol against Fusarium graminearum via inducing lipid peroxidation and disrupting ergosterol biosynthesis. Molecules 2016, 21, 770. [CrossRef]

22. Chen, J.; Peng, H.; Wang, X.; Shao, F.; Yuan, Z.; Han, H. Graphene oxide exhibits broad-spectrum antimicrobial activity against bacterial phytopathogens and fungal conidia by intertwining and membrane perturbation. Nanoscale 2014, 6, 1879-1889. [CrossRef] [PubMed]

23. Xing, K.; Liu, Y.; Shen, X.; Zhu, X.; Li, X.; Miao, X.; Feng, Z.; Peng, X.; Qin, S. Effect of O-chitosan nanoparticles on the development and membrane permeability of Verticillium dahliae. Carbohydr. Polym. 2017, 165, $334-343$. [CrossRef] [PubMed]

24. Duan, J.-L.; Li, X.-J.; Gao, J.-M.; Wang, D.-S.; Yan, Y.; Xue, Q.-H. Isolation and identification of endophytic bacteria from root tissues of Salvia miltiorrhiza Bge. and determination of their bioactivities. Ann. Microbiol. 2013, 63, 1501-1512. [CrossRef]

25. Lateef, A.; Ojo, S.A.; Akinwale, A.S.; Azeez, L.; Gueguim-Kana, E.B.; Beukes, L.S. Biogenic synthesis of silver nanoparticles using cell-free extract of Bacillus safensis LAU 13: Antimicrobial, free radical scavenging and larvicidal activities. Biologia 2015, 70, 1295-1306. [CrossRef]

26. Ming, L.J. Structure and function of "metalloantibiotics". Med. Res. Rev. 2003, 23, 697-762. [CrossRef]

27. Roy, A.; Bulut, O.; Some, S.; Mandal, A.K.; Yilmaz, M.D. Green synthesis of silver nanoparticles: Biomolecule-nanoparticle organizations targeting antimicrobial activity. RSC Adv. 2019, 9, 2673-2702. [CrossRef]

28. Kasithevar, M.; Saravanan, M.; Prakash, P.; Kumar, H.; Ovais, M.; Barabadi, H.; Shinwari, Z.K. Green synthesis of silver nanoparticles using Alysicarpus monilifer leaf extract and its antibacterial activity against MRSA and CoNS isolates in HIV patients. J. Interdiscip. Nanomed. 2017, 2, 131-141. [CrossRef]

29. Sastry, M.; Mayya, K.; Bandyopadhyay, K. pH Dependent changes in the optical properties of carboxylic acid derivatized silver colloidal particles. Colloids Surf. A Physicochem. Eng. Asp. 1997, 127, 221-228. [CrossRef]

30. Ahmed, T.; Shahid, M.; Noman, M.; Niazi, M.B.K.; Mahmood, F.; Manzoor, I.; Zhang, Y.; Li, B.; Yang, Y.; Yan, C. Silver Nanoparticles Synthesized by Using Bacillus cereus SZT1 Ameliorated the Damage of Bacterial Leaf Blight Pathogen in Rice. Pathogens 2020, 9, 160. [CrossRef]

31. Kuppurangan, G.; Karuppasamy, B.; Nagarajan, K.; Sekar, R.K.; Viswaprakash, N.; Ramasamy, T. Biogenic synthesis and spectroscopic characterization of silver nanoparticles using leaf extract of Indoneesiella echioides: In vitro assessment on antioxidant, antimicrobial and cytotoxicity potential. Appl. Nanosci. 2016, 6, $973-982$. [CrossRef]

32. Anthony, K.J.P.; Murugan, M.; Gurunathan, S. Biosynthesis of silver nanoparticles from the culture supernatant of Bacillus marisflavi and their potential antibacterial activity. J. Ind. Eng. Chem. 2014, 20,1505-1510. [CrossRef]

33. Akter, M.; Sikder, M.T.; Rahman, M.M.; Ullah, A.A.; Hossain, K.F.B.; Banik, S.; Hosokawa, T.; Saito, T.; Kurasaki, M.A. Systematic review on silver nanoparticles-induced cytotoxicity: Physicochemical properties and perspectives. J. Adv. Res. 2018, 9, 1-16. [CrossRef] [PubMed]

34. Carlson, C.; Hussain, S.M.; Schrand, A.M.; Braydich-Stolle, L.K.; Hess, K.L.; Jones, R.L.; Schlager, J.J. Unique cellular interaction of silver nanoparticles: Size-dependent generation of reactive oxygen species. J. Phys. Chem. B 2008, 112, 13608-13619. [CrossRef] [PubMed]

35. Suganya, G.; Karthi, S.; Shivakumar, M.S. Larvicidal potential of silver nanoparticles synthesized from Leucas aspera leaf extracts against dengue vector Aedes aegypti. Parasitol. Res. 2014, 113, 875-880. [CrossRef] [PubMed] 
36. Jyoti, K.; Baunthiyal, M.; Singh, A. Characterization of silver nanoparticles synthesized using Urtica dioica Linn. leaves and their synergistic effects with antibiotics. J. Radiat. Res. Appl. Sci. 2016, 9, 217-227. [CrossRef]

37. Ahmed, T.; Shahid, M.; Noman, M.; Niazi, M.B.K.; Zubair, M.; Almatroudi, A.; Khurshid, M.; Tariq, F.; Mumtaz, R.; Li, B. Bioprospecting a native silver-resistant Bacillus safensis strain for green synthesis and subsequent antibacterial and anticancer activities of silver nanoparticles. J. Adv. Res. 2020, 24, 475-483. [CrossRef]

38. Velmurugan, P.; Iydroose, M.; Mohideen, M.H.A.K.; Mohan, T.S.; Cho, M.; Oh, B.-T. Biosynthesis of silver nanoparticles using Bacillus subtilis EWP-46 cell-free extract and evaluation of its antibacterial activity. Bioprocess Biosyst. Eng. 2014, 37, 1527-1534. [CrossRef]

39. Wang, Z.; Xu, C.; Zhao, M.; Zhao, C. One-pot synthesis of narrowly distributed silver nanoparticles using phenolic-hydroxyl modified chitosan and their antimicrobial activity. RSC Adv. 2014, 4, 47021-47030. [CrossRef]

40. Khalil, N.M.; Abd El-Ghany, M.N.; Rodríguez-Couto, S. Antifungal and anti-mycotoxin efficacy of biogenic silver nanoparticles produced by Fusarium chlamydosporum and Penicillium chrysogenum at non-cytotoxic doses. Chemosphere 2019, 218, 477-486. [CrossRef]

41. Pham, D.C.; Nguyen, T.H.; Ngoc, U.T.P.; Le, N.T.T.; Tran, T.V.; Nguyen, D.H. Preparation, characterization and antifungal properties of chitosan-silver nanoparticles synergize fungicide against pyricularia oryzae. J. Nanosci. Nanotechnol. 2018, 18, 5299-5305. [CrossRef]

42. Nicomrat, D.; Janlapha, W.; Singkran, N. In vitro susceptibility of silver nanoparticles on Thai isolated fungus Pyricularia oryzae from oryza sativa L. Leaves. Appl. Mech. Mater. 2017, 866, 148-151. [CrossRef]

43. Akter, R. Efficacy of Silver Nanoparticles Against Rice Blast Disease and Farmers Perception about Its Management in Bangladesh; Swedish University of Agricultural Sciences: Uppsala, Sweden, 2019.

44. Lee, S.H.; Jun, B.-H. Silver nanoparticles: Synthesis and application for nanomedicine. Int. J. Mol. Sci. 2019, 20, 865. [CrossRef] [PubMed]

45. Pariona, N.; Mtz-Enriquez, A.I.; Sánchez-Rangel, D.; Carrión, G.; Paraguay-Delgado, F.; Rosas-Saito, G. Green-synthesized copper nanoparticles as a potential antifungal against plant pathogens. RSC Adv. 2019, 9, 18835-18843. [CrossRef]

46. Oussou-Azo, A.F.; Nakama, T.; Nakamura, M.; Futagami, T.; Vestergaard, M.C.M. Antifungal Potential of Nanostructured Crystalline Copper and Its Oxide Forms. Nanomaterials 2020, 10, 1003. [CrossRef]

47. Wu, D.; Lu, J.; Zhong, S.; Schwarz, P.; Chen, B.; Rao, J. Influence of nonionic and ionic surfactants on the antifungal and mycotoxin inhibitory efficacy of cinnamon oil nanoemulsions. Food Funct. 2019, 10, 2817-2827. [CrossRef]

48. Kriti, A.; Ghatak, A.; Mandal, N. Inhibitory potential assessment of silver nanoparticle on phytopathogenic spores and mycelial growth of bipolaris sorokiniana and alternaria brassicicola. Int. J. Curr. Microbiol. Appl. Sci. 2020, 9, 692-699. [CrossRef]

Publisher's Note: MDPI stays neutral with regard to jurisdictional claims in published maps and institutional affiliations.

(C) 2020 by the authors. Licensee MDPI, Basel, Switzerland. This article is an open access article distributed under the terms and conditions of the Creative Commons Attribution (CC BY) license (http://creativecommons.org/licenses/by/4.0/). 